\title{
Diagnóstico do emprego turístico gerado na cidade de Barreirinhas (MA)
}

\section{Diagnostic of the touristic job at Barreirinhas' city (MA, Brazil)}

\author{
Marcelo Aragão Saldanha, Leonardo Augusto Lobato Bello,
} Maria Lúcia Bahia Lopes, Silvia Helena Ribeiro Cruz

\section{RESUMO}

O trabalho objetiva diagnosticar o emprego turístico, gerado na cidade de Barreirinhas, no estado do Maranhão - ela que é a porta de acesso a uma das belezas naturais mais singulares do mundo, o Parque Nacional dos Lençóis Maranhenses. Para tanto, no que tange a busca das informações inerentes, se estabelece (desde a pesquisa de campo) - a metodologia quantitativa que fundamenta o Índice de Caracterização do Emprego Turístico, o ICET, junto à doze meios de hospedagem empregadores do destino (universo amostral). Quanto aos resultados obtidos, estes apontam para as evidências de um emprego com formatação favorável, devidamente entendido como ideal.

PALAVRAS-CHAVE: Emprego Turístico; Barreirinhas; Maranhão; ICET; Meios de Hospedagem.

\section{ABSTRACT}

The bigger objective about this work to diagnose the touristic job at Barreirinhas, in Maranhão's state, Brazil - what it's the access door for one of the most singulars natural beauties of the world, the National Park of Lençóis Maranhenses. About the search to the own informations, use instruments at the practice work - the numeric method what establish the Caracterization Index of the Touristic Job, the ICET, near the twelve hotels employers of the place (sign universe). At the end, what the get of the results, this one mark for the evidences of one job with favorable aspect - one ideal job.

KEYWORDS: Touristic Tob; Barreirinhas; Maranhão; ICET; Hotels. 


\section{Introdução}

Utilizando-se do desenvolvimento da metodologia quantitativa do Índice de Caracterização do Emprego Turístico (ICET), o artigo proposto objetiva diagnosticar o emprego gerado pela atividade do Turismo, notadamente aquele da ordem dos meios de hospedagem, junto à cidade de Barreirinhas - distante cerca de 270 quilômetros da capital do estado do Maranhão, e porta de entrada do Parque Nacional dos Lençóis Maranhenses, com os seus 150 mil hectares de dunas de areias alvas e finas que se movem ao sabor dos ventos e lagoas cristalinas e profundas, fundamentando assim, discussões sequenciais (ainda pouco existentes), acerca dos impactos econômicos (e logo, sociais) do fenômeno, neste destino verde.

O estudo proposto é didaticamente segmentado em três abordagens distintas e complementares. A primeira delas aproxima Turismo à Economia, reconhecendo, portanto, a geração do emprego e da renda, como uma das suas mais importantes contribuições. Na sequência, caracteriza-se a cidade objeto do estudo, a partir de um entendimento sócio espacial, e em conseguinte, econômico. Por fim, apresenta-se os resultados da pesquisa de campo, realizada em doze meios de hospedagem devidamente cadastrados no Cadastro Nacional de Turismo (CADASTUR) e citados no Guia Brasil 4 Rodas, edição 2015, para fins de caracterização, sobretudo quantitativa (visto o ICET) do emprego turístico gerado, apontando os preliminares resultados deste trabalho científico, para a conclusão de uma situação entendida como ideal.

\section{Fundamentação teórica}

\section{O Turismo e a macro importância econômica.}

O Turismo é uma das atividades contemporâneas que mais apresenta elevação nas suas taxas de crescimento, dado especialmente o aumento do tempo livre - agora entendido como um tempo social e da renda "per capita" da população dos países desenvolvidos (e em desenvolvimento), além das facilidades dos deslocamentos, visto que com a globalização, o mundo ficou menor, logo, de acesso substancialmente facilitado.

Isto sem falar da tecnologia - cada vez mais notada nos meios de transportes, bem como da mídia, que desperta no consumidor, o desejo de conhecer destinos novos a preços tangíveis e condições de pagamento elásticas.

É desde o fim da década de noventa, quando a atividade deixa de ser tão somente um "luxo dos mais endinheirados" e passa a compor o orçamento familiar de muitos outros (ao lado da prestação do carro e da reforma do apartamento), constituindo-se de um bem mais acessível, que o Turismo ganha "status" de importância ainda maior, levando-se em consideração a essência dos seus propósitos e a sua relação dialética com a sociedade, visto que ele ilumina uma gama de processos sociais mais amplos, justificando assim, a sua inclusão junto às discussões da política 
econômica mundial. Desta maneira, conclui Mário Carlos Beni (2001, p.6265):

\begin{abstract}
No Turismo, imagina-se que tanto a área estatal, como aquela empresarial têm como objetivo, o lucro. O Estado espera da atividade, o superávit no balanço de pagamentos na conta específica, em razão do ingresso de divisas e as empresas que atuam no setor, igualmente dimensionam a prestação dos seus serviços, em razão da lucratividade dos investimentos necessários.
\end{abstract}

Uma engrenagem mais complexa de produtos/serviços próprios (sem falar daqueles transversais) surge como uma consequência da motivação profissionalmente tratada, a exemplo da geração de novas frentes produtivas de emprego, bem como do trabalho temporário, muito comum nesta atividade. Segundo Theobald (2002, p.28), "O Turismo congrega 11\% dos trabalhadores assalariados, em média".

Uma série de outros efeitos é também notada, como a renda provida de altos fatores de multiplicação e redistribuição, o que minimiza os desequilíbrios regionais; os tributos inúmeros; as divisas injetadas que culminam com a melhora da balança orçamentária e as maiores perspectivas de ganhos - os tais "desdobramentos sociais" dos tipos educação básica, moradia digna, saneamento, saúde, segurança pública e urbanização, todos destinados aos habitantes do lugar, eles que se constituem dos maiores beneficiados com a iniciativa, e que, portanto, manifestam o interesse da acolhida.

Tudo isto, sem falar da valorização dos imóveis edificados e do acentuado crescimento da construção civil, de todo percebida com a chegada de novos investimentos, especialmente daqueles hoteleiros de bandeiras internacionais, apesar de que, muitos estudiosos os questionam, dado que somente a menor parte do lucro realizado por estes, fica no país, bem como do incremento do parque fabril associado (indústrias de ônibus de turismo, maquinário para restaurantes, por exemplo) e da urbanização mais acentuada, observada na abertura das estradas de acesso.

Segundo Rabahy (2003, p.75) "[...] tudo podendo ser sensivelmente mais visto, em locais que permeiam o desenvolvimento - os mais pobres, uma vez serem preponderantemente receptores", sendo esta, a particularidade de transferência dos benefícios de uma região mais rica, para outra, munida de muitas carências; a notória figuração da renda redistribuída, logo, um alto benefício social.

Um fenômeno que segundo Aguiar e Dias (2002, p.13), "supera setores tradicionais da economia, a exemplo das indústrias automobilística, eletrônica, petrolífera e têxtil', e que desde as estatísticas da Organização Mundial do Turismo (OMT), apontam para cerca de dois bilhões de viagens internacionais, realizadas até 2020 . 
Índices que não devem parar de crescer, visto a geração de novos fluxos que se encarregarão de prover dinâmica sequencial ao desenvolvimento da atividade, a exemplo do que citam Morandi e Gil (2002, p.12) "o aumento das estatísticas da longevidade; a economia globalizada que demandará deslocamentos a negócios e os engajamentos com projetos ecológicos dinamizará este modal de viagens".

Rodrigues (2001, p.19), complementa "casamentos mais tardios e o adiamento do nascimento dos filhos permitirão mais disponibilidade financeira e tempo destinado para o ato de viajar".

Insistindo na questão importância, Ignarra (2003, p.162) fala que "o Turismo promove a conservação do meio natural, pois em muitas regiões é a única atividade econômica desenvolvida", logo, em dadas situações, os atrativos desta ordem são observados com mais critério, sendo comum a criação de áreas de preservação ambiental pós momento exploratório da atividade, e carecendo a riqueza cultural também ser preservada - quando o patrimônio e as práticas históricas de uma gente, se constituem em valores importantes, o que segundo Acerenza (2002, p.162) "[...] acabam culminando com a melhora do nível educacional da população do lugar".

Ressalta-se também, que o contato que se estabelece entre os nativos e os ávidos viajantes - premissa maior e agora muito buscada pelo Turismo de Base Comunitária (TBC), desde o artesanato, das comidas típicas, das danças, das músicas, permite um considerável enriquecimento para ambos, sendo também, uma forma alternativa e muito funcional do intercâmbio das idéias, elas que culminam com o respeito às diferenças dos povos, fortalecendo assim, as suas identidades locais e garantindo a paz entre eles - o ideal de maior sentido axiológico do fenômeno turístico.

Tudo isto, sem falar, que o desenvolvimento da atividade, acontecido na internalidade territorial de um dado país, precisamente na instância da cidade, o coloca em uma vitrine de mundo, a partir de uma imagem construída, figurando o efeito propagador das viagens realizadas. Aquilo que Fernandes e Coelho (2002, p.8), entendem como "Exportação Invisível".

\section{Os empregos gerados pelo Turismo}

Segundo Acerenza (2002, p.42-78) "os estudos econômicos do Turismo, se iniciam quando os economistas percebem que o fenômeno repercute diretamente na balança orçamentária de certos países [...]", e complementa "[...] após a Primeira Guerra Mundial, muitas nações começaram a recolher rendas superiores às das suas exportações, o que fez a atividade ganhar respeito".

Ascher (1984 apud RABAHY, 2003, p.27) considera que "o Turismo passa a ser importante para a economia de um país, quando representa mais que $5 \%$ das suas exportações".

Com a Segunda Guerra Mundial findada e a aviação civil desenvolvida, as distâncias internacionais já não eram tão notadas e o enfoque da comercialização do Turismo substancialmente alterado, origina 
então, o conceito "produto turístico". Carvalho e Vasconcellos (2006, p.87) tratam de detalhá-lo:

Uma combinação de elementos, às vezes concretos e às vezes abstratos, que permitem que as atrações de um determinado destino turístico, sejam ajustadas aos interesses dos turistas consumidores, em relação às possibilidades de acesso e as facilidades da permanência, gerando assim, uma procura turística.

Produto este, manifestado desde a descoberta de novos destinos (oferta turística), especialmente em países com nível intermediário de desenvolvimento, a exemplo de Cuba (a atividade em questão carece de sociedades abertas e livres) e tantos outros, que a partir da década de 70 até os dias atuais, mais se diversificam, ao passo que também se globalizam, tornando-se "intercambiáveis", para a maior satisfação de toda uma demanda consumidora, que só se expande.

É fato, que Turismo e economia sempre estiveram próximos, corroborando com o pensamento de Lage e Milone (2004, p.9) "é difícil pensar em algo que não envolva a economia e que não tenha uma ligação com o lazer e o Turismo", alimentando, portanto, relações do tipo causas e efeitos, estas bem mais fáceis de serem medidas, se comparadas com aquelas ambientais, e como exemplo, podem desde o entendimento de Barreto (2003, p.72), ser classificadas assim:

\begin{abstract}
Efeitos diretos são os que dizem respeito aos gastos do visitante com equipamentos e prestadores de serviços turísticos e indiretos aqueles que resultam das despesas efetuadas por estes mesmos equipamentos e prestadores de serviços turísticos, na compra de bens e serviços de outra ordem, existindo ainda, os efeitos induzidos, que se constituem das despesas realizadas por aqueles que receberam o dinheiro dos prestadores de serviços turísticos.
\end{abstract}

Iniciativas pública e privada se beneficiam com o fenômeno, das formas as mais distintas. Enquanto a primeira arrecada tributos e a partir deles, teoricamente, reverte tudo em mais qualidade de vida aos cidadãos do lugar, dada a construção de escolas e hospitais, por exemplo, se encarregando também, da cobrança de taxas alfandegárias e de vistos de permanência; a segunda se faz constituída de um diverso aglomerado de prestadores de serviços - multiplicadores em efeito.

Ignarra (2001, p.150) cita alguns destes, comumente usados pela Hotelaria - uma atividade consequência do fenômeno: "alimentos e bebidas; enxovais de banho, cama e mesa; equipamentos de cozinha e lavanderia; floricultura; higiene e limpeza; informática, louças, móveis, papelaria, refrigeração, segurança e transporte dos hóspedes, talheres, vidros, dentre outros". 
Fornecedores todos, entendidos por Acerenza (2002, p.161), como "unidades produtoras do setor", e que, segundo o Instituto Brasileiro de Geografia e Estatística (IBGE), mobilizam pouco mais que cinquenta setores da economia do país, participando, portanto, de modo substancial do crescimento dos novos investimentos, destinados ao atendimento não apenas dos turistas, mas também de toda uma comunidade, e respondendo assim, por forte participação no Produto Interno Bruto (PIB), sendo que, em muitos destinos no mundo, isto se faz ainda mais evidente, como nos países caribenhos, a exemplo das Bahamas (ali, o Turismo contribui com $70 \%$ do Produto Interno Bruto, o PIB) e da Jamaica. Neles, o Turismo responde por cerca de $90 \%$ da sua economia, fazendo surgir muito mais empregos.

Lage e Milone (2000, p.118), ao escreverem o artigo científico intitulado Impactos socioambientais globais do Turismo, afirmam que "a geração de empregos em um quantitativo significante é o mais notado dos resultados do fenômeno turístico, uma vez que ele envolve serviços". Arendit (2002, p.94), complementa que "[...] esta expressividade numérica também se dá, em função da tendência a automação ser muito menor neste setor".

Segundo Rabahy (2003, p.68) "[...] ainda que a sua verdadeira quantificação fique limitada, visto a ausência de informações e pesquisas específicas [...]", de acordo com a OMT, a atividade turística gera um em cada onze empregos no mundo, com perspectivas para atingir a marca de um em cada nove, isto sem falar naqueles indiretos, cerca de $6 \%$ do emprego total no mundo.

Já, o multiplicador de base econômica do Turismo, então estimado para o Brasil, fora de 5,56, segundo dados da Fundação Instituto de Pesquisas Econômicas, a FIPE (1984, p. 5-39), indicando que para cada emprego turístico gerado (são cerca de quase dois milhões), existe um incremento de cinco outros empregos mais genéricos.

Portanto, mais uma vez, ressaltando Fernandes e Coelho (2002, p.32) "aproximadamente $10 \%$ da população economicamente ativa do mundo, trabalha em atividades ligadas ao Turismo, muito deste percentual indo ao encontro, sobretudo, dos trabalhadores mais jovens e também, das mulheres", possibilitando assim, um maior grau de independência, para estes grupos sociais, todos preferencialmente alocados no próprio destino aproveitamento da mão de obra local.

Os jovens, que educando-se, se veem mais preparados junto à garantia das suas empregabilidades, que de acordo com Minarelli (1995, p.17) é a "condição de ser empregável, conseguir emprego para os seus conhecimentos e habilidades", prerrogativa esta, fundamentada também, desde o mesmo Minarelli (1995, p. 49-68) em alguns pilares, a exemplo da "[...] adequação vocacional, da competência para o trabalho, da idoneidade, da saúde e da reserva financeira".

E as mulheres, que mais empregadas, postula Acerenza (2002, p.136), são providas de "[...] salários similares aos dos homens, especialmente na hotelaria". Elas que, para tanto, permeiam tais mudanças, visto razões de natureza econômica, como o aumento da renda mínima 
familiar, uma vez que muitas são "mães solteiras" e dividem as responsabilidades domésticas com as jornadas de trabalho, bem como psicossocial - mudança de seu "status" na sociedade contemporânea (a sua emancipação), ambas atreladas às novas oportunidades estabelecidas.

Fonteles (2004, p.155), conclui, afirmando que "as mulheres, que antes eram apenas donas de casa, passam a trabalhar nas pousadas $e$ restaurantes, sendo que outras instalam vendas diversas, em locais onde 0 turista circula com mais frequência".

Nos Estados Unidos, especialmente em meio aos parques da Disney, na Flórida, é comum observar também, a alta incidência de idosos, respondendo por serviços turísticos, a exemplo de motoristas de ônibus e vendedores de lojas de "souvenirs", o que ocasiona o surgimento do trabalho, ainda que temporário, por vezes, inserido na chamada "economia informal", cabendo considerar desde Senac (2000, p.10-11) que "o atual movimento da sociedade, nos aponta para o esgotamento das condições de pleno emprego, que no Brasil, nunca chegou a ser extensivo aos mais ampliados setores da população [...]", e complementando ainda: "[...] 0 mundo moderno exige novas formas de trabalho. Outras modalidades destas relações surgem, a exemplo daquelas com parcialidade da jornada, da subcontratação, do tele trabalho e do trabalho por projeto - com início, meio e fim".

Atualmente, a economia globalizou-se, e logo, as empresas mudaram - inclusive, as turísticas, tornando-se compactadas, mudando também, as suas maneiras de absorção da mão de obra, que precisa estar mais qualificada, visto os sucessivos redesenhos, para não falar das reduções de cargos e acúmulo das rotinas, o que incorre na descentralização das decisões, aumentando assim, a responsabilidade dos poucos contratados, sendo fato, que junto às frentes de trabalho estabelecidas no Turismo, a maioria dos seus profissionais, as encaminham de maneira autônoma, fazendo surgir o auto empresariamento, o profissional "free lancer", a exemplo dos garçons de temporada e guias de turismo, aquilo que o Dupas (1999, p.146), chama de "trabalho informal ou flexível".

Por outro lado, é válido desconsiderar, desde a discussão da atividade turística, quaisquer realidades de exploração laboral infantil, como aquela que também se observa, ao longo de todo o lendário Peru, onde crianças pobres - normalmente meninas, ainda muito pequenas, são "induzidas" a vestirem-se com o colorido dos tecidos andinos, para junto das ruínas incas, comporem um cenário perfeito para os turistas deslumbrados.

E tudo devendo culminar para a geração de renda não vazada - os gastos dos visitantes nos lugares visitados (com os nativos, ali devidamente empregados) se constituem de novos recursos (moeda internacional) injetados na economia local e de um equilíbrio na balança orçamentária, também, segundo Acerenza (2002, p.160), com "[...] o incentivo à diminuição da saída das divisas, desde o incremento das viagens domésticas". 
Daí os países em vias de desenvolvimento, a exemplo da África do Sul, pós-queda do "Apartheid" e do Chile, que sucede o seu rigoroso regime militar, se voltarem para o desenvolvimento do setor.

Wahab (1977, p.93) complementa estas discussões, permeando acerca da saudável redistribuição das divisas:

O Turismo é um dos fatores redistributivos mais acertados nas relações econômicas internacionais [...] Uma parte substancial das viagens ao exterior é dirigida à regiões em desenvolvimento, que normalmente são mais atrativas, talvez por não terem sido ainda estragadas pela industrialização. Portanto, o Turismo realoca a renda entre países desenvolvidos e aqueles em vias de.

\section{Caracterização socioespacial e econômica da área de estudo - A cidade turística de Barreirinhas}

Segundo os dados do IBGE (2015), a cidade de Barreirinhas detém uma área territorial de aproximadamente $3025 \mathrm{~km}^{2}$, estando localizada no nordeste do estado do Maranhão, na mesorregião do Norte, na microrregião da Baixada Oriental ou dos Lençóis Maranhenses, e distando cerca de 270 km a leste, da capital São Luís.

O Índice de Desenvolvimento Humano do Município (IDHM), em 2010, foi de 0,570 - considerado de baixa escala, se comparado com aquele da capital São Luís, em mesmo ano, de 0,768 (alta escala).

Sua população detém um pouco mais de 60 mil habitantes residentes, que vivem em um núcleo urbano minimamente organizado, sendo a religião católica predominante (cerca de 66\%) - um contingente populacional sazonal, que aumenta em tempos de feriados e férias.

É uma região rica em plantações do buriti, muito usado pelos nativos para a cobertura das suas casas e na produção de doces. A pesca ainda responde por um papel importante junto da economia do lugar, especialmente no que tange a subsistência das comunidades mais pobres habitualmente, famílias inteiras são vistas comercializando os seus excedentes no cais da cidade, à beira do rio Preguiças, a principal via fluvial da região.

Ao lado desta prática, os citadinos também sobrevivem do cultivo da castanha do caju, visto a exportação para o estado do Ceará, sendo ela, o mais importante produto agrícola do lugar, assim como da fabricação artesanal da farinha de mandioca.

O comércio local é cada vez mais multifacetado, ainda existindo as antigas mercearias que se utilizam da caderneta para a tomada dos pedidos a serem pagos no mês seguinte, como também, as lojas grifadas de cosméticos e as operadoras de telefonia móvel, sendo que ainda cultiva o hábito (provinciano) de fechar as suas portas depois do meio dia, visto o descanso do almoço e o forte calor que se instala nestas horas. Com estas 
práticas, Lima (2008, p.59), fala que "Os habitantes do município, ainda guardam muito das suas tradições culturais."

Com o povoamento do município datado de 1850, e tendo sido elevada à categoria de Paróquia em 1858, o município de Barreirinhas, foi segundo Ramos (2008, p.34) "Emancipado como cidade em 1938, fazendo parte da comarca de Araióses, e só na década de 70 experimentou um notável crescimento econômico, quando a Petrobrás fincou ali a sua bandeira, ensaiando a prospecção de petróleo e gás natural". Desta forma, o lugar tomado de otimismo, vislumbrava o término de todo o seu isolamento histórico.

Quanto a sua inclinação para a atividade turística, esta se revelou no término da década de 90 , dado o interesse da então gestão pública estadual, materializada no polêmico Plano de Desenvolvimento Integral do Turismo - o Plano Maior, de revelar para todo o mundo, o que comercialmente se constituía de um dos "Segredos do Maranhão", portanto, o Parque Nacional dos Lençóis Maranhenses, também nela incrustado.

Segundo Silva (2008, apud FIBRAS, 2012, p.11) "entre os anos de 2000 a 2007, a oferta dos meios de hospedagem esteve aumentada em 330\%", sendo eles, em sua grande maioria da propriedade de migrantes, que se viam atraídos pelo Turismo ali instalado. Acerca deste cenário, Yázigi (2003, p.127) trata com bastante clareza:

A estradinha de terra ganha asfalto; surge uma pequena pousada, um posto de gasolina, os prestadores de serviços turísticos, um restaurante; os carros chegam e os loteamentos também. A pressa em ganhar dinheiro fácil, aliada à displicência administrativa, que interpreta todo início de empreendimento, como fator de progresso.

No que tange aos deslocamentos para o destino, até o início do ano de 2002, que antecede a construção da MA-402, a Translitorânea, estrada que interliga a cidade às rodovias BR 135 e 222, chegar à Barreirinhas por meio do acesso literal por estrada de terra, significava viajar desconfortavelmente e de maneira muito perigosa, visto sobretudo, as travessias rudimentares dos igarapés e riachos, por um tempo aproximado de nove horas, em meio ao calor e a poeira, então inerentes características do caminho. De acordo com Ramos (2008, p.141) com a construção da Translitorânea, o trajeto foi encurtado em mais de $100 \mathrm{~km}$ e impulsionou, consideravelmente o Turismo na região.

Mais recentemente, em Janeiro de 2014, investimentos da ordem de 4 milhões de Reais, aportados pelo governo federal através do Ministério do Turismo, culminam com a homologação da parte da Agência Nacional de Aviação Civil (ANAC), do aeroporto da cidade, podendo a partir de então, ser ele operado por rotas áreas regulares e vôos "charters", fretados por grandes operadoras turísticas, encurtando ainda mais as distâncias todas, e maximizando a diversidade da demanda. 
Em outra abordagem, de todo relacionada à reconfiguração do território, e sobretudo, à economia local - mais dinamizada com o Turismo, observa-se que o fluxo dos habitantes da cidade de Barreirinhas é cada vez mais crescente, uma vez que muitos trocaram o campo e a vizinhança ribeirinha pela sede, para então trabalhar neste setor.

A questão do emprego, que também impacta diretamente na espacialidade urbana, uma vez que, a população evadida do seu inicial trabalho agrário torna a produção local dos alimentos diminuída, o que por fim, incorre em outro efeito, igualmente econômico (e ali observado) - o considerável aumento dos seus preços.

Já aqueles que buscavam a capital, na disposição de ingressarem em uma atividade laboral diferente, permaneceram. Isto sem falar dos "forasteiros" que chegaram ao lugar, movidos pelo novo cenário de possibilidades estabelecido, se encarregando, inclusive, de elevar o valor dos imóveis consideravelmente, caracterizando assim, o maléfico entrave da especulação imobiliária.

Figurando novas frentes de importância produtiva, o artesanato, que é fonte de trabalho e renda para mais de oito milhões de brasileiros, em Barreirinhas é uma realidade encaminhada pela mesma força laboral, que o Casasola (2003, p.64) postula existir em outros destinos "[...] mulheres, seus filhos e maridos, estes últimos em época de inatividade agrícola", sendo que na cidade, a maioria deles, agora, permanecem mais organizados em associações e cooperativas, no intento de maximizar a gestão da atividade, dando um sentido mais pleno de valor ao objeto do seu trabalho.

A partir de Buriti (2010, p.5), em um catálogo de produtos do próprio Sebrae, as gestoras do então projeto Comércio Justo e Solidário do Artesanato Maranhense da Fibra do Buriti, sublinham "a prática do trabalho artesanal, assegura aos núcleos, a possibilidade concreta de inclusão social, geração de renda e desenvolvimento sustentável para cada um". Tudo em uma região, que detém os mais baixos Índices de Desenvolvimento Humano (IDH) do país.

\section{Material e método utilizados.}

\section{O lócus e o universo amostral da pesquisa.}

O "lócus" deste trabalho é a cidade de Barreirinhas - junto aos bairros rigorosamente localizados em seu perímetro urbano (Figura 1). Por outro lado, como unidades amostrais, se estabelece uma parte compreendida (doze meios de hospedagem) no todo hoteleiro citadino, provida de (i) cadastro válido junto ao Cadastro Nacional de Turismo, o CADASTUR, e (ii) citação no Guia Brasil Quatro Rodas, ano 2015, edição especial dos seus cinquenta anos de publicação (fechada em Setembro de 2014 e publicada pela Editora Abril), tendo se constituído estes, como os principais critérios para suas inclusões na pesquisa. 


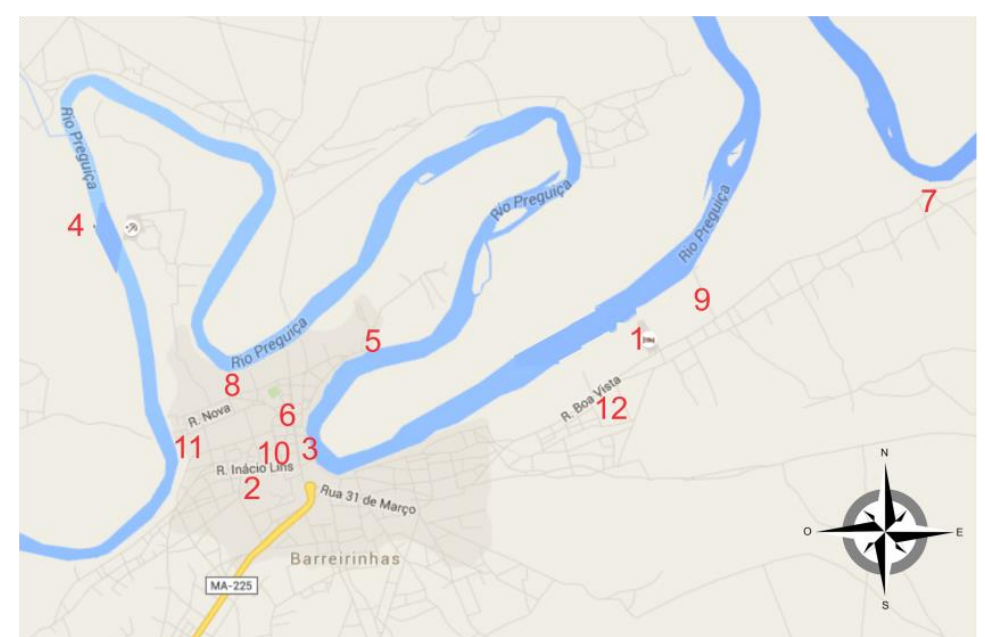

\author{
LEGENDA: \\ 1 - Gran Solare Lençóis Flat \\ 2 - Hotel Pousada Buriti \\ 3 - Inventure Pousada \\ 4 - Porto Preguiças Resort \\ 5 - Pousada Beira Rio \\ 6 - Pousada Belo Horizonte \\ 7 - Pousada Boa Vista \\ 8 - Pousada do Rio \\ 9 - Pousada Encantes do Nordeste \\ 10 - Pousada Igarapé \\ 11 - Pousada Murici \\ 12 - Pousada Vila dos Lençóis
}

Figura 1: Os estabelecimentos hoteleiros, unidades amostrais, localizados no perímetro urbano (próximos ao rio) da cidade de Barreirinhas.

Figure 1: The hotels, sign unities, all of them at the urban area (near the river) -

Barreirinhas'city.

Fonte: Adaptação do autor ao Google Maps (2016).

Source: Author's adaptation to Google Maps (2016).

Segundo Senac (2000, p.12) "[...] as oportunidades do emprego são muito mais difusas na hotelaria do que no agenciamento de viagens e em outras frentes do Turismo, onde estas declinam, visto as facilidades atuais da internef", daí justificada, a escolha do estudo do emprego gerado na localidade, vinculado tão somente a este segmento da atividade turística, caracterizado pela sua ramificação abrangente de muitas frentes de trabalho.

É o que Pimenta (2004, p.25-31) discorre como características individuais das empresas turísticas, figurando o hotel, a partir de "uma grande variedade de tamanhos, logo se fazendo necessário, equipes de trabalhos especializadas [...]". Ele mesmo, ainda complementa "[...] um quarto de hotel construído, gera 0,4 a 2 empregados diretos".

Por fim, a amostra investigada junto a estes estabelecimentos hoteleiros, foi constituída de doze profissionais ouvidos, sendo sete, os gerentes gerais, e cinco, os proprietários, entendidos como sujeitos deste estudo, ainda que as informações, próprias do questionário (em anexo), objeto da caracterização do emprego, tenham sido todas da natureza dos seus geridos, agrupados em um nível mais operacional de trabalho, portanto, os atendentes dos bares, as camareiras dos andares, os cozinheiros, os garçons, os jardineiros, os mensageiros e os porteiros, os recepcionistas, além dos mais administrativos, dentre outros.

\title{
O procedimento da coleta dos dados
}

Este se viabilizou com o uso do instrumental investigativo aplicação de um questionário estruturado (em anexo), disposto a partir de doze perguntas fechadas, respondidas após as necessárias buscas, junto aos 
registros profissionais dos empregados destes meios de hospedagens questionados. As indagações estiveram providas de características quantitativas (informações são de natureza numérica), ainda que de modo complementar, não se tenha desprezado as abordagens qualitativas, presentes nas falas mais espontâneas dos próprios entrevistados, observando o item 4 dele - Outras observações importantes.

No Quadro 1, detalha-se o instrumento trabalhado, portanto 0 Questionário (em anexo) e as suas partes constitutivas, além das variáveis de estudo e as suas respectivas descrições, muitas delas, a exemplo de distribuição geográfica, escolaridade, experiência profissional e tempo no emprego, gênero e salário, definidas sob a orientação dos estudos de Arbache (2001, p. 23-60).

Quadro 1: Partes constitutivas do questionário e as suas respectivas variáveis de estudo descritas.

Table 1: Parts of the questionnaire and theirs variants of the study.

\begin{tabular}{|c|c|c|c|}
\hline $\begin{array}{c}\text { PARTE } \\
\text { CONSTITUTIVA }\end{array}$ & ABORDAGEM & $\begin{array}{l}\text { VARIÁVEL DE } \\
\text { ESTUDO (VE) }\end{array}$ & DESCRIÇÃO \\
\hline Parte 1 & $\begin{array}{c}\text { Síntese do } \\
\text { empreendimento. }\end{array}$ & & $\begin{array}{l}\text { Dados preliminares do meio de } \\
\text { hospedagem. }\end{array}$ \\
\hline Parte 2 & $\begin{array}{l}\text { Síntese do } \\
\text { entrevistado. }\end{array}$ & - & Inferências profissionais do gestor. \\
\hline \multirow{11}{*}{ Parte 3} & \multirow{11}{*}{$\begin{array}{l}\text { Caracterização do } \\
\text { emprego. }\end{array}$} & VE1 & $\begin{array}{c}\text { Admissões realizadas entre } \\
2005 / 2015 .\end{array}$ \\
\hline & & VE2 e VE3 & $\begin{array}{l}\text { Razões para crescimento ou não, } \\
\text { do volume de empregos. }\end{array}$ \\
\hline & & VE4 & Faixa etária dos funcionários. \\
\hline & & VE5 & $\begin{array}{l}\text { Distribuição por gênero dos } \\
\text { funcionários. }\end{array}$ \\
\hline & & VE6 & Estado civil dos funcionários. \\
\hline & & VE7 & $\begin{array}{l}\text { Histórico da vida laboral dos } \\
\text { funcionários. }\end{array}$ \\
\hline & & VE8 & $\begin{array}{l}\text { Origem da moradia dos } \\
\text { funcionários. }\end{array}$ \\
\hline & & VE9 & $\begin{array}{l}\text { Dificuldades na contratação dos } \\
\text { funcionários. }\end{array}$ \\
\hline & & VE10 & Faixa salarial dos funcionários. \\
\hline & & VE11 & $\begin{array}{l}\text { Percentual dos funcionários } \\
\text { providos de casa própria. }\end{array}$ \\
\hline & & VE12 & $\begin{array}{l}\text { Percentual dos funcionários com } \\
\text { filhos matriculados em escola } \\
\text { privada. }\end{array}$ \\
\hline Parte 4 & $\begin{array}{l}\text { Outras } \\
\text { informações } \\
\text { importantes. }\end{array}$ & - & $\begin{array}{l}\text { Acréscimos de outros dados } \\
\text { característicos do emprego, } \\
\text { ofertados quando das entrevistas. }\end{array}$ \\
\hline
\end{tabular}

Fonte: Dos autores (2016).

Source: Author's (2016). 


\section{A análise do emprego}

Com a disposição de realizar uma análise mais quantitativa do emprego gerado na cidade de Barreirinhas, desde os equipamentos do tipo meios de hospedagem, é proposta a aplicação do Índice de Caracterização do Emprego Turístico (ICET).

Tal índice é determinado pela soma dos pontos atribuídos a cada uma das variáveis de estudo, descritas no Quadro 1. Por sua vez, cada VE recebe uma pontuação que varia de 1 a 3 pontos, em função da resposta ofertada pelo sujeito da pesquisa, conforme ilustra o Quadro 2, onde o valor 3 representa o cenário de maior relação, predispondo-se um fator desejado (alta relação do Turismo com o emprego), enquanto que o valor 1 denota a figuração contrária.

Quadro 2: Valoração das variáveis de estudo e relação das respostas do questionário com o emprego.

Table 2: Variants' value of the study and the relation of the questionnaire with the job.

\begin{tabular}{|c|c|}
\hline VALORAÇÃO DA VE & RELAÇÃO RESPOSTA/ EMPREGO \\
\hline 3 & Alta \\
\hline 2 & Moderada \\
\hline 1 & Baixa \\
\hline
\end{tabular}

Fonte: Dos autores (2016)

Source: Author's (2016).

Assim, a valoração máxima para cada um dos questionários aplicados é de 36 pontos, enquanto que a mínima é de 12 pontos, concluindo-se, portanto, ser o ICET, o somatório das doze notas atribuídas a cada variável do estudo.

Conclusivamente, o ICET representa a relação do Turismo com a geração do emprego, aumento da renda e da qualidade de vida, onde os seus valores mais significativos implicam em afirmar que o fenômeno turístico movimenta o destino, induzindo assim, uma maior participação da população local na economia que se desenvolve, constituindo-se, portanto, em uma maneira de mensurar o efeito da atividade sobre uma determinada comunidade.

Neste sentido, se a partir de Lemos (1999, p.22), "[...] é possível medir o Turismo, desde os empregos gerados", pode-se também valorar estes empregos, em importância conceitual (a exemplo de alta, moderada ou ainda baixa), usando-se desta metodologia.

A valoração do ICET, para fins de interpretação do emprego é proposta nesta pesquisa, obedecendo as escalas valorativas, evidenciadas no Quadro 3, sendo importante ressaltar que as devidas interpretações de caráter mais qualitativo (estas advindas das falas mais espontâneas dos 
entrevistados) a cada uma das variáveis concluídas, também se faz presente no trabalho, até para fundamentar um mais pleno entendimento da relação estabelecida entre a atividade turística e o emprego gerado.

Quadro 3: Escalas valorativas do ICET e a relação do Turismo com o emprego

Table 3: Value's scales of the ICET and the relation the Tourism with the job.

\begin{tabular}{|c|c|}
\hline ESCALAS VALORATIVAS DO ICET & RELAÇÃO TURISMO/EMPREGO \\
\hline $12<\mathrm{ICET} \leq 20$ & BAIXA \\
\hline $20<\mathrm{ICET} \leq 28$ & MODERADA \\
\hline $28<\mathrm{ICET} \leq 36$ & ALTA \\
\hline
\end{tabular}

Fonte: Dos autores (2016)

Source: Author's (2016).

\section{Resultados obtidos e discussões inerentes.}

\section{Diagnóstico regional do emprego e definição do ICET.}

$\mathrm{Na}$ pesquisa de campo foi realizado um diagnóstico do emprego formal, gerado na cidade de Barreirinhas, especificamente a partir dos equipamentos turísticos do tipo Meios de Hospedagem - hotéis, pousadas e resorts, providos dentre outros requisitos, da inclusão válida no CADASTUR (exceto a Pousada Inventure, na ocasião recém inaugurada, e ainda sem registro - atualmente Pousada Village - altos da sorveteria Frutos do Goiás).

O Quadro 4 apresenta as características básicas dos estabelecimentos, entendidos como unidades amostrais. Nele, a coluna intitulada Ano da abertura evidencia a quão embrionária é a atividade turística no destino (apesar de se manifestar em crescente expansão), uma vez que o mais antigo dos empreendimentos hoteleiros citados, o Hotel Pousada Buriti, inicia as suas atividades no ano de 1998.

Quadro 4: Características dos estabelecimentos hoteleiros, unidades amostrais da pesquisa.

Table 4: Characteristics of the hotels, sign unities of the study.

\begin{tabular}{|l|c|c|c|c|}
\hline \multicolumn{1}{|c|}{ NOME } & TIPO & CADASTUR & $\begin{array}{c}\text { ANO DA } \\
\text { ABERTURA }\end{array}$ & $\begin{array}{c}\text { NÚMERO } \\
\text { DE UHs. }\end{array}$ \\
\hline $\begin{array}{l}\text { Gran Solare Lençóis } \\
\text { Flat }\end{array}$ & Resort & $10.005183 .20 .0005-5$ & 2005 & 97 \\
\hline Hotel Pousada Buriti & Hotel & $10.024528 .20 .0001-9$ & 1998 & 33 \\
\hline Inventure Pousada & Pousada & AINDA SEM REGISTRO & 2015 & 07 \\
\hline Porto Preguiças Resort & Resort & $10.022816 .20 .0001-5$ & 2002 & 44 \\
\hline Pousada Beira Rio & Pousada & $10.043535 .20 .0001-6$ & 2005 & 25 \\
\hline Pousada Belo Horizonte & Pousada & $10.011548 .20 .0001-4$ & 2007 & 18 \\
\hline Pousada Boa Vista & Pousada & $10.070344 .20 .0001-1$ & 2008 & 20 \\
\hline Pousada do Rio & Pousada & $10.002899 .20 .0001-0$ & 2002 & 26 \\
\hline $\begin{array}{l}\text { Pousada Encantes do } \\
\text { Nordeste }\end{array}$ & Pousada & $10.037731 .20 .0002-0$ & 2003 & 28 \\
\hline Pousada lgarapé & Pousada & $10.032177 .20 .0001-6$ & 2003 & 16 \\
\hline $\begin{array}{l}\text { Pousada Murici } \\
\text { Pousada Vila dos }\end{array}$ & Potel & $10.002548 .20 .0001-5$ & 2002 & 24 \\
\hline \begin{tabular}{l} 
Lençóis \\
\hline
\end{tabular} & Pousada & $10.055897 .20 .0001-8$ & 2013 & 12 \\
\hline
\end{tabular}

Fonte: Dos autores (2015).

Source: Author's (2015). 
Seis, dos doze alvos da pesquisa são entregues ao mercado desde o ano de 2005, acrescentando ao destino, 159 unidades habitacionais novas e somando uma média de 358 outros leitos.

É procedente registrar ainda, que o maior meio de hospedagem da cidade, inclusive, em número de absorção da mão de obra - o Gran Solare Lençóis Resort, atualmente ainda é administrado por uma rede hoteleira internacional, a Brazilian Hospitality Group (BHG), o que teoricamente eleva as exigências para o emprego.

Segundo Lage e Milone (2000, p.127), "no mundo, os resorts são símbolos de melhores empregos na área, sendo eles, objetos de uma intensa migração daqueles que procuram trabalhar na hotelaria, ainda que não estejam aptos".

Iniciou-se toda a pesquisa, com o encaminhamento da indagação "Quantidade de funcionários admitidos atualmente e quantidade de funcionários admitidos no ano de 2005", indo ao encontro da variável primeira do estudo (VE1), portanto "Admissões realizadas entre 2005/2015 Desenvolvimento do destino, a partir da atividade". O Quadro 5, explicita tais números, e em uma das suas colunas, atribui ponto do tipo 3 , caso haja crescimento neste intervalo; do tipo 2, em tudo se mantendo sem alterações; e do tipo 1, dado um eventual decréscimo, no período.

Quadro 5: VE1 da caracterização do emprego “Admissões realizadas entre 2005/2015 -

Desenvolvimento do destino, a partir da atividade"

Table 5: VE1 of the job's characterization "Admissions doing between 2005/2015 Development of the place, since the activity."

\begin{tabular}{c|c|c|c}
\hline MEIO DE HOSPEDAGEM & $\begin{array}{c}\text { FUNCIONÁRIOS } \\
\text { EM 2005 }\end{array}$ & $\begin{array}{c}\text { FUNCIONÁRIOS } \\
\text { EM 2015 }\end{array}$ & $\begin{array}{c}\text { PONTO } \\
\text { ATRIBUÍDO }\end{array}$ \\
\hline Gran Solare Lençóis Flat & 53 & 47 & 1 \\
\hline Hotel Pousada Buriti & 25 & 35 & 3 \\
\hline Inventure Pousada & Inaugurada em 2015 & 03 & 3 \\
\hline Porto Preguiças Resort & 40 & 60 & 3 \\
\hline Pousada Beira Rio & 04 & 07 & 3 \\
\hline Pousada Belo Horizonte & Inaugurada em 2007 & 03 & 3 \\
\hline Pousada Boa Vista & Inaugurada em 2008 & 07 & 3 \\
\hline Pousada do Rio & 04 & 22 & 3 \\
\hline Pousada Encantes do Nordeste & 09 & 20 & 3 \\
\hline Pousada Igarapé & 05 & 06 & 3 \\
\hline Pousada Murici & 07 & 15 & 2,84 \\
\hline Pousada Vila dos Lençóis & Inaugurada em 2013 & 05 & \\
\hline TOTÁ DAS ADMISSÕES / & 147 & 230 & \\
MÉDIA DOS PONTOS & & & 3 \\
\hline
\end{tabular}

Fonte: Dos autores (2015).

Source: Author's (2015).

Analisados os dados, percebeu-se que quatro das doze unidades amostrais, iniciaram as suas atividades após o ano de 2005, o que se convencionou, sob o ponto de vista dos pontos atribuídos, como um acréscimo de mão de obra disponibilizada ao mercado (logo, todas ganharam ponto tipo 3). 
Foi possível concluir que, no ano de 2005, havia 147 empregos hoteleiros diretos gerados, ao passo que, uma década depois, como consequência do desenvolvimento da atividade no destino, este número cresceu cerca de $56,46 \%$, contabilizando-se 230 , sendo a média dos pontos, para esta variável (VE1), a de 2,84, onde onze dos estabelecimentos hoteleiros pesquisados, obtiveram cada um deles, o ponto tipo 3 , visto 0 crescimento no quantitativo dos empregos em uma década, ao passo que apenas um obteve o ponto tipo 1, em virtude do decréscimo no período.

Seguindo a lógica do questionário e com o intento de justificar o crescimento do volume de empregos gerados a partir da dinâmica turística, no intervalo destes dez anos, se foi à procura das razões que fundamentam a realidade então desenhada, elas que se constituem, portanto, da próxima variável de estudo, a VE2 "Razões para crescimento do volume de emprego - Desenvolvimento do destino, a partir da atividade", que também compõe o ICET.

Neste sentido, basicamente quatro respostas foram disponibilizadas para esta indagação, munidas cada uma delas, de um valor, conforme mostra o Quadro 6.

Quadro 6: Pontos atribuídos às respostas da VE2, "Razões para crescimento do volume de emprego - Desenvolvimento do destino, a partir da atividade"

Table 6: Points for the answers of the VE2, "Reasons for the progress of the job's volume Development of the place, since the activity".

\begin{tabular}{|c|c|}
\hline RAZÃO PARA CRESCIMENTO DO EMPREGO & $\begin{array}{c}\text { SEU PONTO } \\
\text { RESPECTIVO }\end{array}$ \\
\hline Ampliação física das instalações & 2 \\
\hline Maior complexidade/diversidade dos serviços oferecidos & 3 \\
\hline Ocupação com índices maiores, visto crescimento do destino & 3 \\
\hline Crescimento não acontecido & 1 \\
\hline
\end{tabular}

Fonte: Dos autores (2015).

Source: Author's (2015).

Aos estabelecimentos inaugurados depois de 2005 (quatro ao todo, já citados no Quadro 5), portanto, desprovidos de um número de funcionários empregados naquele ano, atribuiu-se como resposta, a opção "Ampliação física das instalações" (ponto tipo 2), ainda que esta, tenha sido entendida, de fato, como "Início das instalações" tendo-se permeado de forma mais geral, a seguinte situação:

Em seis dos estabelecimentos hoteleiros estudados, o crescimento do volume de emprego, deu-se a parir da ampliação física das instalações, um fato observado nas Inventure Pousada, Pousada Belo Horizonte, Pousada Boa Vista, Pousada do Rio, Pousada Murici e Pousada Vila dos Lençóis (seis pontos tipo 2). Já nas unidades amostrais Porto Preguiças Resort, Pousada Beira Rio, Pousada Encantes do Nordeste e Pousada Igarapé, ele é justificado por meio da ocupação que cresce em seus índices, dado o desenvolvimento do destino (quatro pontos tipo 3). 
O Hotel Pousada Buriti vai ao encontro da maior complexidade/diversidade dos serviços oferecidos para justificar 0 crescimento do quantitativo de empregos (um ponto tipo 3) e o Gran Solare Lençóis Resort retrata um crescimento não acontecido (um ponto tipo 1), ele que ao longo desta década, precisou rever o seu quadro funcional de características mais operacionais, reduzindo-o em número (Quadro 5), sendo a média dos pontos, para esta variável (VE2), a de 2,34.

A exemplo do que foi feito junto da VE2, no que diz respeito a VE3, "Razões para decréscimo do volume de emprego - Desenvolvimento do destino, a partir da atividade", também quatro respostas foram estabelecidas a este questionamento, sendo um valor específico, vinculado a cada uma delas, conforme trata o Quadro 7.

Quadro 7: Pontos atribuídos às respostas da VE3, "Razões para decréscimo do volume de emprego - Desenvolvimento do destino, a partir da atividade".

Table 7: Points for the answers of the VE3, "Reasons for the fall of the job's volume Development of the place, since the activity".

\begin{tabular}{|c|c|}
\hline RAZÃO PARA DECRÉSCIMO DO EMPREGO & $\begin{array}{c}\text { SEU PONTO } \\
\text { RESPECTIVO }\end{array}$ \\
\hline Redução física das instalações & 1 \\
\hline Menor complexidade/diversidade dos serviços oferecidos & 1 \\
\hline Ocupação com índices menores, visto declínio do destino & 3 \\
\hline Decréscimo não acontecido & 1 \\
\hline
\end{tabular}

Fonte: Dos autores (2015).

Source: Author's (2015).

Aqui, onze dos estabelecimentos pesquisados, não se vincularam a um eventual decréscimo no quantitativo dos empregos gerados (onze pontos tipo 3), o que só reforça, o já tratado desenvolvimento do destino ao longo dos anos, associado à natural geração de empregos.

Apenas a amostra Gran Solare Lençóis Resort reduz o seu volume, nesta década, atribuindo para tanto, a menor complexidade/diversidade dos serviços oferecidos (um ponto tipo 1), podendo citar como exemplos, as necessárias demissões de jardineiros, visto a opção pelo encaminhamento de trabalhos terceirizados (empregos indiretos) nesta área - cada vez mais, uma tendência na hotelaria, sendo a média dos pontos, para esta variável (VE3), a de 2,84.

Ainda acerca dos empregos indiretos, Acerenza (2002, p.121), os caracterizam como "aqueles adicionais que se derivam em atividades conexas, relacionadas com o desenvolvimento das facilidades, próprias do setor", e Ruschmann (1997, p.43), os figuram a partir dos "originados em empresas que prestam serviços aos fornecedores diretos".

Quanto a variável de estudo "Faixa etária dos funcionários - O Emprego ideal para o Turismo - Os jovens e os mais idosos", quatro diferentes intervalos de idades foram disponibilizados, com associação de um determinado valor para cada um deles, sendo que os maiores (ponto tipo 3) foram concedidos aos mais jovens (18 a 24 anos) e idosos (mais de 46 
anos), faixas etárias que carecem de serem reconhecidas pelo mercado turístico, como aquelas muito apropriadas para o trabalho. O Quadro 8, então cita.

Quadro 8: Pontos atribuídos às respostas da VE4, "Faixa etária dos funcionários - O emprego ideal para o Turismo - Os jovens e os mais idosos".

Table 8: Points for the answers of the VE4, "Age of the employeds - The youngs and the olders".

\begin{tabular}{|c|c|}
\hline INTERVALO DE IDADE & SEU PONTO RESPECTIVO \\
\hline 18 a 24 anos & 3 \\
\hline 25 a 30 anos & 2 \\
\hline 31 a 45 anos & 2 \\
\hline Mais de 46 anos & 3 \\
\hline
\end{tabular}

Fonte: Dos autores (2015)

Source: Author's (2015).

Apenas a Inventure Pousada reconhece que os seus empregados, encontram-se na primeira (18 a 24 anos), das faixas etárias do quadro acima (um ponto tipo 3).

Os estabelecimentos Porto Preguiças Resort, Pousada Beira Rio, Pousada Belo Horizonte, Pousada do Rio e Pousada Encantes do Nordeste inserem o seu corpo funcional, no segundo intervalo das idades, portanto de 25 a 30 anos (cinco pontos tipo 2).

Os Gran Solare Lençóis Resort, Hotel Pousada Buriti, Pousada Boa Vista, Pousada Igarapé, Pousada Murici e Pousada Vila dos Lençóis dispõem de empregados entre 31 a 45 anos (seis pontos tipo 2).

Nenhuma das amostras coletadas, contrata maiores de 46 anos, junto as suas frentes mais operacionais, sendo a média dos pontos, para esta variável (VE4), a de 2,08.

Sempre reconhecido nas falas dos entrevistados, como bastante baixo (até quase, inexistente), há indícios de que o "turn over" seja o maior responsável pela não admissão dos mais jovens, visto que a permanência alongada em número de anos, no trabalho na mesma empresa, fez com que aqueles da primeira faixa (18 a 24 anos), hoje já estivessem permeando a segunda ( 25 a 30 anos) e a terceira (31 a 45 anos), onde os números da pesquisa são mais notados.

Em Barreirinhas, tais dados contrariam a afirmativa de Arbache (2001, p.46) "[...] no setor do Turismo, a rotatividade produtiva é muito alta".

Os mais velhos (para a pesquisa, acima de 46 anos), também na cidade do estudo, a partir da realidade encontrada, ainda permanecem exclusos da formalidade do mercado de trabalho em questão.

Junto às doze unidades amostrais da pesquisa é válido o registro da não observância de quaisquer evidências, do que Rodrigues (2000, p. 57), intitula de "inclusão precoce e criminosa de trabalho com crianças e adolescentes", trabalho que segundo a Comissão para a Erradicação do Trabalho Infantil da Justiça do Trabalho (CETI) do Tribunal Superior do 
Trabalho, é o "realizado de maneira indiscriminada, pelos que detém idade inferior a dezesseis anos, salvo na condição de aprendiz, quando a idade permitida passa a ser de quatorze anos".

Avançando no Diagnóstico do emprego, analisa-se a variável de estudo "Distribuição por gênero dos funcionários - A mulher no mercado de trabalho que se expande com o Turismo", reconhecida como a quinta de uma série (VE5), sendo o que explicita o Quadro 9, acerca dos pontos associados para cada um dos sexos admitidos. O maior deles, portanto 0 tipo 3, foi alocado para o sexo feminino, até então, sempre muito à margem do mercado de trabalho, especialmente em cidades menores.

Quadro 9: Pontos atribuídos às respostas da VE5, "Distribuição por gênero dos funcionários - A mulher no mercado de trabalho que se expande com o Turismo".

Table 9: Points for the answers of the VE5, "Distribution for the gender of the employeds The woman at the touristic labor Market".

\begin{tabular}{|c|c|}
\hline GENERO & SEU PONTO RESPECTIVO \\
\hline Feminino & 3 \\
\hline Masculino & 2 \\
\hline \multicolumn{3}{|c|}{ Fonte: Dos autores (2015). } \\
Source: Author's (2015).
\end{tabular}

Como resultado dos doze meios de hospedagem tratados, apenas quatro, empregam um quantitativo mais significativo de homens, com destaque para os maiores em número de empregados, portanto o Gran Solare Lençóis Resort (alta incidência de mensageiros, porteiros e recepcionistas) e o Porto Preguiças Resort (neste, muitos jardineiros), ao passo que os oito restantes, registram empregadas mulheres com mais notoriedade numérica, sendo a média dos pontos, para esta variável (VE5), a de 2,67 .

A fala da proprietária da Pousada Murici, sra. Agar de Carvalho Mota, quando da aplicação do questionário, traça um perfil acerca da mulher atualmente empregada na hotelaria local, "é aquela que começou a trabalhar como diarista nas casas de veraneio das famílias ricas e adquiriu assim, novas referências de conforto e entretenimento desta classe social [...]" e ainda complementa " [...] ela, antes do Turismo, ajudava o marido nos trabalhos da extração do buriti e também da pesca, e agora, reconhece a necessidade de incrementar a pouca instrução, voltando para a escola" (informação verbal).

A professora Monique Serra, coordenadora do eixo de Hospitalidade e Turismo, do IFMA campus Barreirinhas, corrobora com tais afirmativas da executiva hoteleira, quando sintetiza acerca do que observa, desde a demanda dos discentes do Programa de Ensino para Jovens e Adultos, 0 PROEJA, do governo federal, "Na grande maioria, nossos alunos são mulheres adultas, que agora trabalham fora do lar, tendo deixado os estudos por longos anos, para cuidar da casa e criar os filhos" (informação verbal). 
Rodrigues (1997, p.57) diz que "o Turismo tem a força necessária para a vasta absorção da mão de obra da mulher, ela que por muitas outras vezes é sozinha e chega a chefiar famílias inteiras, carecendo do emprego".

Acerca deste entendimento, pesquisas do IBGE evidenciam que no Brasil, uma em cada cinco estruturas familiares é gerida pelo sexo feminino, não se constituindo este suposto quadro, como algo estranho no destino em questão.

Outra abordagem manifestada na quase totalidade das entrevistas vai ao encontro da afirmativa dos empregadores, de que as mulheres são as que mais estabelecem laços com o emprego, sendo organizadas e polivalentes (nas pequenas pousadas, esta habilidade em especial, se faz muito necessária). Na mesma observação dos executivos entrevistados, os homens desejam dispor de uma experiência empregatícia mais temporal, se identificando, em sobremaneira, com o trabalho por estação.

Estudada a distribuição dos funcionários empregados no destino, por meio do substrato do gênero, seguiu-se junto a VE6, portanto, "Estado civil dos funcionários - A menor submissão feminina ao marido provedor, visto o trabalho que se desenvolve com o Turismo."

A partir de então, quatro situações distintas, foram tratadas como respostas, sendo que os maiores pontos (tipo 3), seguiram atribuídos aos solteiros com filhos e aos separados (com destaque para as mulheres, que com o emprego, ficam menos suscetíveis aos "mandos" dos seus cônjuges), como mostra o Quadro 10.

Quadro 10: Pontos atribuídos às respostas da VE6, "Estado civil dos funcionários - A menor submissão feminina ao marido provedor, visto o trabalho que se desenvolve com o Turismo". Table 10: Points for the answers of the VE6, "Civil condition of the employeds - The smaller woman's submission of the supplier's man, seen the touristic job".

\begin{tabular}{|c|c|}
\hline ESTADO CIVIL & $\begin{array}{c}\text { SEU PONTO } \\
\text { RESPECTIVO }\end{array}$ \\
\hline Solteiros sem filho(s) & 2 \\
\hline Solteiros (destaque $\mathrm{p} /$ as mulheres/mães) com filho (s) & 3 \\
\hline Casados (destaque $\mathrm{p} /$ os recém) sem ou com filho (s) & 2 \\
\hline Separados (destaque $\mathrm{p} /$ as mulheres) & 3 \\
\hline
\end{tabular}

Fonte: Dos autores (2015).

Source: Author's (2015).

Três estabelecimentos dispõem em seus registros, de um maior quantitativo de funcionários solteiros sem filho(s), sendo eles, Inventure Pousada, Pousada Beira Rio e Pousada Vila dos Lençóis (três pontos tipo 2), ao passo que apenas um, a Pousada Belo Horizonte, se constitui em número mais significativo, daqueles solteiros (precisamente mulheres) com um ou mais filhos (um ponto tipo 3), figurando-se os outros oito estabelecimentos, como os providos de funcionários casados (oito pontos tipo 2). Nenhuma das amostras coletadas emprega aqueles separados, desde as suas frentes mais operacionais, sendo a média dos pontos, para esta variável (VE6), a de 2,08\%. 
Quanto a maior das incidências, relativas ao estado civil dos funcionários alvos da pesquisa, portanto, "Casados sem ou com filhos", na verdade, estes em sua grande maioria, a partir das afirmações dos entrevistados, vivem maritalmente, como se casados fossem. Os dados do IBGE - Estatísticas do Registro Civil, ano de 2013, corroboram com a realidade encontrada, uma vez que em tal ano, apenas oitenta e quatro matrimônios foram realizados na cidade.

Tal evidência encontra-se muito relacionada, daquela anterior da "Faixa etária", quando a preponderância dos números, foi ao encontro dos 25 a 30 anos e dos 31 a 45 anos, o que se pode indiciar, que os operacionais da hotelaria da região, já não tão jovens, são "casados", podendo ser isto, uma influência direta da tão falada "segurança" do emprego (acerca disto, foi concluído, em outro momento do estudo, que os empregados do setor, passam longos anos, junto a um mesmo empregador).

A partir do Diagnóstico do emprego gerado, se entende ser necessário, que a abordagem acerca do "Histórico da vida laboral dos funcionários - Outras perspectivas de trabalho, desde o Turismo Diversidade dos arranjos produtivos citadinos", se faça presente. Em sendo, cinco diferentes origens empregatícias são tratadas no Quadro 11, munida cada uma delas, de um ponto respectivo.

Quadro 11: Pontos atribuídos às respostas da VE7, "Histórico da vida laboral dos funcionários - Outras perspectivas de trabalho, desde o Turismo - Diversidade dos arranjos produtivos citadinos".

Table 11: Points for the answers of the VE7, "History of the labor's life of the employeds -

Others perspectives of the touristic job - Variety of the productives arrangements' city".

\begin{tabular}{|c|c|}
\hline ORIGEM EMPREGATÍCIA & $\begin{array}{l}\text { SEU PONTO } \\
\text { RESPECTIVO }\end{array}$ \\
\hline Advindos do extrativismo primário (agricultura/pecuária) & 3 \\
\hline Advindos dos pequenos comércios da região & 2 \\
\hline Advindos da atividade do Turismo, com outras experiências & 2 \\
\hline Em situação de término da escolaridade (média profissionalizante) & 3 \\
\hline Em situação de longo desemprego & 3 \\
\hline
\end{tabular}

Fonte: Dos autores (2015).

Source: Author's (2015).

Apenas os atuais funcionários da unidade Pousada Boa Vista estavam antes empregados no extrativismo primário, precisamente na agricultura e na pecuária (um ponto tipo 3). Vieram dos pequenos comércios da região, os atuais admitidos dos Gran Solare Lençóis Resort, Pousada Beira Rio, Pousada Belo Horizonte e Pousada Encantes do Nordeste (quatro pontos tipo 2).

Contabilizavam experiências anteriores, também na atividade turística (em agências de viagens, restaurantes, etc), os atuais funcionários dos estabelecimentos Hotel Pousada Buriti, Inventure Pousada, Pousada do Rio e Pousada Vila dos Lençóis (quatro pontos tipo 2). 
A situação de longo desemprego foi uma realidade observada, nos corpos funcionais das unidades Porto Preguiças Resort, Pousada Igarapé e Pousada Murici (três pontos tipo 3).

Nenhuma das amostras coletadas emprega, em maior escala, aqueles em término da escolaridade nas suas frentes mais operacionais, o que caracteriza uma evidência preocupante, até em função do estabelecimento de instituições de formação profissional no destino, a exemplo do IFMA e do SEBRAE, sendo a média dos pontos, para esta variável (VE7), a de 2,34.

No que diz respeito, a variável seguinte (VE8), portanto, "Origem da moradia dos funcionários - Absorção da mão de obra turística, já estabelecida na cidade", foram admitidas duas opções básicas de tratativas, sendo que os pontos associados a cada uma delas, são apresentados no Quadro 12, e o maior deles, o tipo 3, concedido aos nativos.

Quadro 12: Pontos atribuídos às respostas da VE8, “Origem da moradia dos funcionários Absorção da mão de obra turística, já estabelecida na cidade".

Table 12: Points for the answers of the VE8," Origin of the employeds' residence Absorption of the touristic job".

\begin{tabular}{|c|c|}
\hline ORIGEM DA MORADIA & SEU PONTO RESPECTIVO \\
\hline Nascidos na cidade de Barreirinhas, vivendo nela & 3 \\
\hline Advindos/trazidos de outras localidades & 1 \\
\hline
\end{tabular}

Fonte: Dos autores (2015).

Source: Author's (2015).

Todos os hotéis, pousadas e resorts que constituem a pesquisa, responderam que os seus empregados são nascidos na cidade de Barreirinhas e permanecem vivendo nela (doze pontos tipo 3). Segundo os entrevistos, eventualmente, apenas aqueles do nível de gerenciamento (não objeto do estudo), são os advindos ou trazidos de outras localidades, precisamente da capital São Luís, para trabalhos ali, sobretudo desde as maiores estruturas hoteleiras, a exemplo dos resorts, eles que, mais uma vez, repetindo as abordagens de Rodrigues (1997, p.92), "necessitam de mão de obra especializada, especialmente junto às médias e altas chefias, com tendências para o recrutamento em centros mais dinâmicos", sendo a média dos pontos, para esta variável (VE8), a máxima de 3.

É procedente ainda, registrar a fala do então gerente geral da Pousada Encantes do Nordeste, Antônio da Cruz Pires, que é a mesma da grande parte dos outros empregadores, "Quando das admissões dos empregados residentes em Barreirinhas, me preocupo com os seus endereços, uma vez que a cidade ainda não é servida de linhas regulares de ônibus" (informação verbal).

A indagação "Dificuldades na contratação dos funcionários Debilidades encontradas junto a formação profissional já estabelecida no lugar", define a variável nona do estudo (VE9).

O Quadro 13, ilustra individualmente cada uma delas, e em uma das suas colunas, já atribui os seus pontos respectivos, destacando aquele 
moderado, do tipo 2, para a resposta "Pouca experiência profissional similar", uma vez que para muitos empregadores, isto se figura até mesmo como um fator positivo, dada a possibilidade que dispõem de "moldar" os seus recém-admitidos.

Quadro 13: Pontos atribuídos às respostas da VE9, "Dificuldades na contratação dos funcionários - Debilidades encontradas junto a formação profissional já estabelecida no lugar". Table 13: Points for the answers of the VE9, "Difficulties at the job's contraction - Fragilities with the profissional education at the place".

\begin{tabular}{|c|c|}
\hline DIFICULDADE NA CONTRATAÇÃO & $\begin{array}{c}\text { SEU PONTO } \\
\text { RESPECTIVO }\end{array}$ \\
\hline $\begin{array}{c}\text { Pouca escolaridade (formação básica/profissionalizante, } \\
\text { informática, línguas) }\end{array}$ & 1 \\
\hline Pouca experiência profissional similar & 2 \\
\hline Jornada de trabalho significativa em dados períodos & 1 \\
\hline Salários baixos ofertados & 1 \\
\hline
\end{tabular}

Fonte: Dos autores (2015).

Source: Author's (2015).

O Gran Solare Lençóis Resort, a Inventure Pousada, a Pousada Boa Vista e a Pousada do Rio reconheceram que a Pouca Escolaridade se constitui da maior dificuldade para contratação dos seus empregados (quatro pontos tipo 1), ainda que o Ministério do Turismo (BRASIL, 2014, p.16), por meio do Índice de Competitividade do Turismo Nacional, na dimensão, Serviços e Equipamentos Turísticos, assinale em Barreirinhas "a presença de instituições que ofertam cursos livres e técnicos regulares, a exemplo do SEBRAE e do IFMA, como de influência positiva, junto ao tal indicador".

Rabahy (2003, p.136) não reconhece isto como um problema, quando conclui em seus estudos "por serem atividades prestadoras de serviços, a hotelaria e o Turismo, têm a vantagem de requerer pessoal com um amplo espectro de qualificação, inclusive aquele com menor nível de escolaridade".

Os estabelecimentos Hotel Pousada Buriti, Pousada Beira Rio, Pousada Belo Horizonte, Pousada Encantes do Nordeste, Pousada Igarapé e Pousada Murici, já citam a Pouca Experiência Profissional Similar, como o maior entrave para o proposto (seis pontos tipo 2), parecendo ser esta, na visão dos empregadores locais, a maior das dificuldades para as definições do emprego.

Pimenta (2004, p.37) afirma que "o requisito mais considerado para a contratação nos empreendimentos hoteleiros é a experiência profissional, sendo ela, mais valorizada que o domínio de outros idiomas e as referências".

O Porto Preguiças Resort e a Pousada Vila dos Lençóis asseguraram ser a Jornada de Trabalho Significativa em Dados Períodos, o mais delicado dos fatores inibidores das admissões (dois pontos tipo 1). Nenhuma das amostras coletadas associa os Salários Baixos Ofertados, como uma dificuldade, sendo a média dos pontos, para esta variável (VE9), a de 1,5. 
Através dos relatos dos entrevistados, uma variável bem mais contemporânea, agora dificulta as tratativas de efetivar o empregado na hotelaria. Trata-se do benefício do cartão Bolsa Família, um programa do Ministério do Desenvolvimento Social e Combate à Fome, concedido àqueles mais pobres, com renda familiar mensal por pessoa, compreendida entre 77 a 154 reais, providos de filhos menores.

Aos beneficiados por este repasse, assim como os outros, que por diferentes razões, não podem/querem permanecer empregados, em virtude da característica da Sazonalidade, muito própria do Turismo inserido em destinos de lazer, trabalhos temporários, pagos em diárias (que oscilam entre 30 a 50 reais), são comumente ofertados pelo mercado hoteleiro em Barreirinhas, especialmente nos meses tidos como de alta estação, sendo também para o empregador, uma forma simples de redução dos seus custos de operação.

Por outro lado, do Ministério do Turismo (BRASIL, 2014, p.37), a partir do atual Índice de Competitividade do Turismo Nacional, tomado mais uma vez como referência, agora, a partir da dimensão Aspectos Sociais, figura esta mão de obra como "informal e muito passível de comprometer a satisfação dos serviços ofertados, uma vez que não constitui vínculo", reconhecendo-a como "fator limitante para a evolução do indicador", ainda que sob o ponto de vista estritamente econômico, também se encarregue de dinamizar os negócios do lugar.

A variável décima "Faixa salarial dos funcionários - Remuneração recebida pelos trabalhadores do Turismo, comparada a outros segmentos", reconhecida como importante, junto da figuração do emprego gerado no destino, passa a ser estudada. A partir de então, são ofertadas três possibilidades de respostas a esta indagação, conforme retrata o Quadro 14, concluindo-se como a de maior ponto (tipo 3), aquela "Salário base da categoria", uma vez que tal pesquisa, trata dos admitidos operacionais da hotelaria na região.

Quadro 14: Pontos atribuídos às respostas da VE10, "Faixa salarial dos funcionários Remuneração recebida pelos trabalhadores do Turismo, comparada a outros segmentos".

Table 14: Points for the answers of the VE10, "Wage of the employeds - Payment of the touristic employeds, compared with others segments".

\begin{tabular}{|c|c|}
\hline FAIXA SALARIAL & SEU PONTO RESPECTIVO \\
\hline Menos que o salário base da categoria & 1 \\
\hline Salário base da categoria & 3 \\
\hline 02 a 03 salários mínimos & 2 \\
\hline
\end{tabular}

Fonte: Dos autores (2015).

Source: Author's (2015).

Todos os estabelecimentos estudados nesta pesquisa pagam aos seus empregados, o salário base (doze pontos tipo 3) estabelecido pela categoria já organizada, através do Sindicato dos Trabalhadores no Comércio Hoteleiro, Motéis, Pousadas, Bares e Restaurantes de Barreirinhas e da Região dos Lençóis Maranhenses (SINDEHOTÉIS), salário 
que chega a ser um pouco superior aquele mínimo, sendo a média dos pontos, para esta variável (VE10), a máxima de 3.

É importante ressaltar, que uma das doze amostras desta pesquisa, não procede o registro dos seus funcionários em carteira, junto ao Ministério do Trabalho, sendo este, um direito constitucional garantido do trabalhador brasileiro.

Acerca disto, Arbache (2001, p.55) fala que "em destinos que experimentam a sazonalidade ou que requerem trabalhadores com pouca qualificação, as relações de trabalho são mais tênues e os contratos informais resistem".

Fonteles (2004, p.156) também discute, com muita propriedade, este temário "muitas das relações de trabalho no Turismo são pautadas na informalidade, sendo que o poder público local é conivente com tal prática, uma vez que se abstém dos mecanismos da fiscalização".

As duas últimas perguntas do questionário (VE11 e VE12) se inclinam para um entendimento da qualidade de vida aumentada (ou não), através do emprego estabelecido.

A primeira delas define o percentual dos funcionários, providos de casa própria, que se entende inicialmente, ter sido adquirida, visto a oportunidade laboral existente. Quatro faixas foram então estipuladas, associando-se cada uma, com um ponto respectivo, desde o que pode ser visualizado no Quadro 15.

Quadro 15: Pontos atribuídos às respostas da VE11, "Percentual dos funcionários, providos de casa própria - Poder de compra desde o trabalho - Aumento na qualidade de vida, advindo com a atividade".

Table 15: Points for the answers of the VE11, "Percentage of the employeds with own house - Power of buy since the job - Addition of the life's qualitity since the activity".

\begin{tabular}{|c|c|}
\hline $\begin{array}{c}\text { PERCENTUAL DOS FUNCIONÁRIOS, } \\
\text { PROVIDOS DE CASA PRÓPRIA }\end{array}$ & SEU PONTO RESPECTIVO \\
\hline 10 a $40 \%$ & 1 \\
\hline 41 a $60 \%$ & 2 \\
\hline 61 a $80 \%$ & 3 \\
\hline 81 a $100 \%$ & 3 \\
\hline
\end{tabular}

Fonte: Dos autores (2015)

Source: Author's (2015).

Os funcionários das unidades Gran Solare Lençóis Resort, Hotel Pousada Buriti e Pousada Inventure (três pontos tipo 2), inserem-se na faixa 41 a $60 \%$ daqueles providos de casa própria.

Os admitidos dos Porto Preguiças Resort, Pousada Beira Rio, Pousada Encantes do Nordeste e Pousada Vila dos Lençóis (quatro pontos tipo 3), estão inseridos na faixa 61 a $80 \%$ daqueles providos de casa própria.

Os outros, evidência dos estabelecimentos Pousada Belo Horizonte, Pousada Boa Vista, Pousada do Rio, Pousada Igarapé e Pousada Murici 
(cinco pontos tipo 3), contabilizam a faixa 81 a $100 \%$ daqueles providos de casa própria, sendo a média dos pontos, para esta variável (VE11), a de 2,75 .

As unidades pesquisadas, em quase toda a totalidade, afirmam que a maior parte dos seus empregados, quando admitidos, possuíam as suas casas próprias, tendo com o emprego efetivado e mantido, realizado nelas, ampliações e melhorias diversas.

Por fim, a variável de estudo décima segunda (VE12), define o percentual dos funcionários com filhos em idade escolar, matriculados em escola privada, reconhecida por este estudo, como aquela a mais ideal.

Os mesmos intervalos de realidades percentuais, estipulados à VE11, foram aqui associados a um ponto particular, a partir do que se explicita no Quadro 16.

Quadro 16: Pontos atribuídos às respostas da VE12, "Percentual dos funcionários com filhos em idade escolar, matriculados em escola privada - Poder de compra desde o trabalho - Aumento na qualidade de vida, advindo com a atividade".

Table 16: Points for the answers of the VE12, "Percentage of the employeds with descendents at the private school - Power of buy since the job - Addition of the life's qualitity since the activity".

\begin{tabular}{|c|c|}
\hline $\begin{array}{c}\text { PERCENTUAL DOS FUNCIONÁRIOS, COM } \\
\text { FILHOS EM ESCOLA PRIVADA }\end{array}$ & SEU PONTO RESPECTIVO \\
\hline 10 a $40 \%$ & 1 \\
\hline 41 a $60 \%$ & 2 \\
\hline 61 a $80 \%$ & 3 \\
\hline 81 a $100 \%$ & 3 \\
\hline
\end{tabular}

Fonte: Dos autores (2015).

Source: Author's (2015).

Em $100 \%$ das amostras coletadas no trabalho, os empregados, no que concerne aos seus filhos em idade escolar, matriculados em escola privada, permeiam a faixa 10 a $40 \%$ (doze pontos tipo 1). Através desta evidência, concluiu-se, portanto, que a significativa parte destas crianças, encontram-se estudando nas escolas públicas do destino, sendo a média dos pontos, para esta variável (VE12), a mínima de 1.

O então gerente geral do Hotel Pousada Buriti, Carlos Kerluylys Rodrigues da Silva, revela que "a mensalidade cobrada pelas instituições privadas de ensino aqui, chega a uma média de 220 reais, o que representa cerca de $25 \%$ do salário, que os funcionários da pousada recebem [...]", e em detrimento a esta escolha de uma mais acertada educação dos filhos, ele complementa "[...] todos optam pela compra em parcelas a perder de vistas, de uma moto, até para deslocarem-se com mais rapidez, também para o trabalho" (informação verbal).

Integrando o questionário proposto, a sua última parte registra eventuais observações importantes, tendo sido colhidas quando das entrevistas, através do pesquisador, visto as falas (aqui, não provocadas pelas doze indagações estruturadas) dos sujeitos da pesquisa, 
acrescentadas à caracterização do emprego no destino, com destaque, para as que passam a ser citadas:

A grande maioria dos meios de hospedagem estudados tem consciência da força produtiva do Turismo, logo, sabem que a partir dos seus negócios, outros empregos e trabalhos indiretos são gerados no município, incitando assim, as práticas sistêmicas de responsabilidade social, a exemplo da compra de parte dos seus insumos no comércio local (açougues, padarias, peixarias e supermercados); do reconhecimento das competências do lugar, em atendimento às necessidades diversas dos hóspedes (babás, cabelereiros, cuidadores de idosos, massagistas e manicuras) e do próprio estabelecimento (contratação de empregados da construção civil), assim como da terceirização dos cuidados com a jardinagem e das lavanderias.

O então gerente de hospedagem do Porto Preguiças Resort, Diego Birino, evita quaisquer contratações temporárias, visto os períodos das lotações, sendo a razão para isto, aquela manifestada em sua fala "nossos sessenta empregados atuais estão preparados para atender poucos ou a totalidade dos apartamentos ocupados [...]", acrescentando ainda "[...] temos preocupação com o padrão dos serviços oferecidos, e os diaristas, não entendem isto" (informação verbal).

Observou-se também, especialmente nas pousadas menores, que a relação estabelecida entre empregadores e empregados é mais afetiva, que por vezes, profissional. Isto se faz evidência, a partir de relatos semelhantes, ao da proprietária da Pousada Boa Vista, Guerlain Pers Marques "minhas funcionárias gostam de trabalhar aqui. Eu as ajudo no que precisam, e elas retribuem, atendendo bem, os nossos hóspedes" (informação verbal). Em outra amostra do estudo, a Pousada do Rio, sua proprietária, Adriana Aragão Oliveira, relata a dificuldade em empregar algumas frentes operacionais do hotel, a exemplo do encarregado de manutenção, "em Barreirinhas, não existe este profissional pronto. Às vezes, acha-se o pintor que não sabe de elétrica, o bombeiro hidráulico que não sabe pintar".

Portanto, em tendo sido analisadas as doze variáveis de estudo, visto as respostas dos questionários aplicados, atreladas aos seus respectivos pontos, e em um segundo momento, posto estes dados complementares advindos da parte 4 - Outras Informações Importantes, extraídos dos mesmos questionários, conclui-se com o levantamento dos resultados encontrados, portanto, com a própria definição numerária responsável pela Caracterização do Emprego Turístico em cada estabelecimento hoteleiro estudado, e por consequência, no destino, dado o seu Índice, o ICET. Na Tabela 2, tais dados são evidenciados. 
Tabela 1: Resultados por unidade amostral do somatório das doze variáveis, com os pontos encontrados para cada uma das respostas do questionário - Definições do ICET por hotel e do destino

Table 1: Results for sign unity of the amount at the twelve variants, with the points for the each answer of the questionnaire.

\begin{tabular}{|c|c|c|c|c|c|c|c|c|c|c|c|c|c|}
\hline HOTÉIS & VE1 & VE2 & VE3 & VE4 & VE5 & VE6 & VE7 & VE8 & VE9 & VE10 & VE11 & VE12 & $\begin{array}{l}\text { ICET } \\
\text { por } \\
\text { HOTEL }\end{array}$ \\
\hline $\begin{array}{c}\text { Gran Solare } \\
\text { Lençois Resort }\end{array}$ & 1 & 1 & 1 & 2 & 2 & 2 & 2 & 3 & 1 & 3 & 2 & 1 & 21 \\
\hline $\begin{array}{c}\text { Hotel Pousada } \\
\text { Buriti } \\
\end{array}$ & 3 & 3 & 3 & 2 & 3 & 2 & 2 & 3 & 2 & 3 & 2 & 1 & 29 \\
\hline $\begin{array}{c}\text { Inventure } \\
\text { Pousada } \\
\end{array}$ & 3 & 2 & 3 & 3 & 2 & 2 & 2 & 3 & 1 & 3 & 2 & 1 & 27 \\
\hline $\begin{array}{c}\text { Porto Preguiças } \\
\text { Resort }\end{array}$ & 3 & 3 & 3 & 2 & 2 & 2 & 3 & 3 & 1 & 3 & 3 & 1 & 29 \\
\hline $\begin{array}{c}\text { Pousada Beira } \\
\text { Rio }\end{array}$ & 3 & 3 & 3 & 2 & 2 & 2 & 2 & 3 & 2 & 3 & 3 & 1 & 29 \\
\hline $\begin{array}{c}\text { Pousada Belo } \\
\text { Horizonte }\end{array}$ & 3 & 2 & 3 & 2 & 3 & 3 & 2 & 3 & 2 & 3 & 3 & 1 & 30 \\
\hline $\begin{array}{c}\text { Pousada Boa } \\
\text { Vista }\end{array}$ & 3 & 2 & 3 & 2 & 3 & 2 & 3 & 3 & 1 & 3 & 3 & 1 & 29 \\
\hline Pousada do Rio & 3 & 2 & 3 & 2 & 3 & 2 & 2 & 3 & 1 & 3 & 3 & 1 & 28 \\
\hline $\begin{array}{c}\text { Pousada } \\
\text { Encantes do } \\
\text { Nordeste }\end{array}$ & 3 & 3 & 3 & 2 & 3 & 2 & 2 & 3 & 2 & 3 & 3 & 1 & 30 \\
\hline $\begin{array}{l}\text { Pousada } \\
\text { Igarapé }\end{array}$ & 3 & 3 & 3 & 2 & 3 & 2 & 3 & 3 & 2 & 3 & 3 & 1 & 31 \\
\hline Pousada Murici & 3 & 2 & 3 & 2 & 3 & 2 & 3 & 3 & 2 & 3 & 3 & 1 & 30 \\
\hline $\begin{array}{l}\text { Pousada Vila } \\
\text { dos Lençóis }\end{array}$ & 3 & 2 & 3 & 2 & 3 & 2 & 2 & 3 & 1 & 3 & 3 & 1 & 28 \\
\hline $\begin{array}{l}\text { MÉDIA por } \\
\text { VE/ICET do } \\
\text { DESTINO }\end{array}$ & 2,84 & 2,34 & 2,84 & 2,08 & 2,67 & 2,08 & 2,34 & 3 & 1,5 & 3 & 2,75 & 1 & 28,44 \\
\hline
\end{tabular}

Fonte: Dos autores (2015)

Source: Author's (2015).

Conclusivamente se percebe, que das doze unidades amostrais, oito (sombreadas em verde, na Tabela 1) detêm o ICET instalado na escala valorativa maior que 28 e menor ou igual a 36 pontos, o que permite definir que $66,7 \%$ do universo amostral pesquisado, se enquadra naquilo que convencionou-se chamar de "Alta relação do Turismo com o emprego", sendo que as quatro restantes (sombreadas em laranja, na mesma Tabela), detêm o ICET instalado na escala valorativa maior que 20 e menor ou igual a 28 pontos, enquadrando-se em uma "Moderada relação do Turismo com o emprego."

De modo mais geral, o ICET do destino Barreirinhas (sombreado em azul, na Tabela 1), tendo atingido 28,44 pontos, também se enquadrou na escala valorativa maior que 28 e menor ou igual a 36 pontos, estando provido o lugar, de uma "Alta relação do Turismo com o emprego", conforme ilustra a Figura 2. 


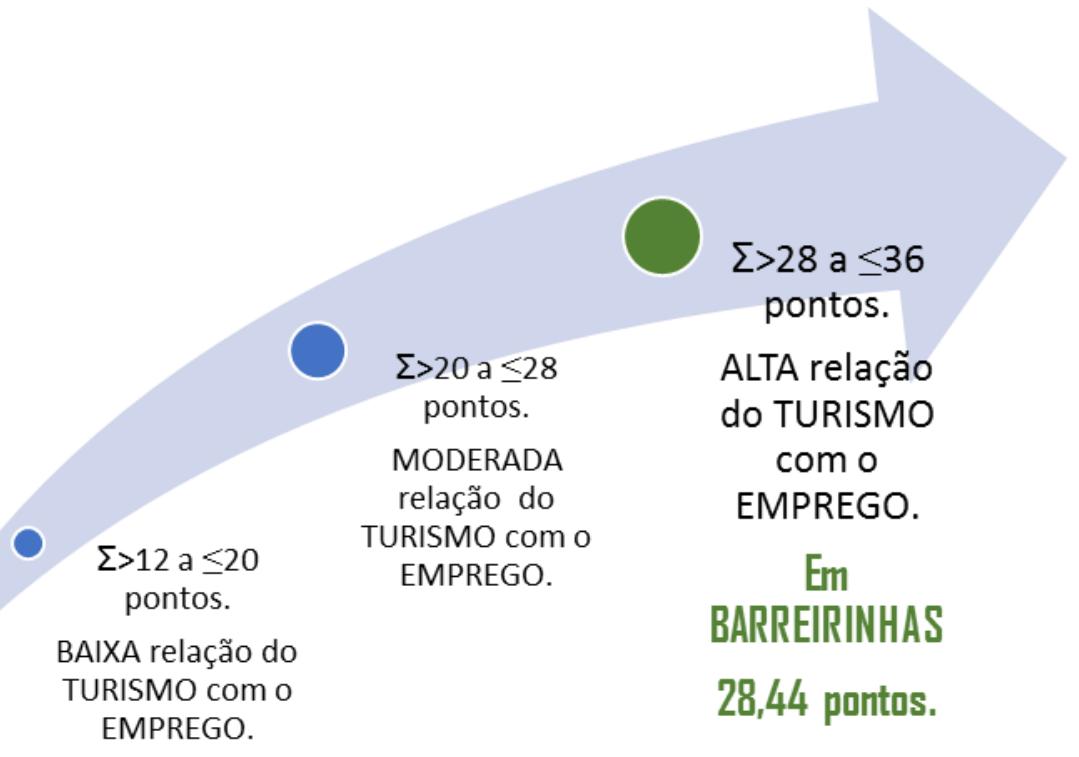

Figura 2: O ICET do destino Barreirinhas - alta relação do Turismo com o emprego.

Figure 2: The ICET in Barreirinhas - high relation of the Tourism and the job.

Fonte: Dos autores (2015).

Source: Author's (2015).

\section{Conclusões}

Em Barreirinhas, acerca do emprego diagnosticado, dado o Turismo que ali se consolida nos últimos dez anos, o resultado das doze unidades amostrais hoteleiras, segue ao encontro do crescimento do número de empregos formais gerados, visto que em 2005, estes contabilizavam 147, e em 2015, 230 - um percentual acrescido de quase $60 \%$.

Emprego caracterizado, através do índice desenvolvido pelo estudo, o ICET, como de alta relação com a atividade turística, somando, 28,4 pontos e enquadrando-se, portanto, na escala valorativa desejada - maior que $28 \mathrm{e}$ menor ou igual a 36 pontos.

Ele que, além de constituir-se de favoráveis traçados, uma vez que absorve os autóctones, os jovens e as mulheres, tendo baixa rotatividade em tempo de jornada e remunerações equiparadas, ainda consegue, em momentos mais pontuais, fazer gerar outros trabalhos agregados, derivados em atividades correlatas, culminando com o aumento da renda, logo, com a diminuição das desigualdades sociais mais notadas, em um município ainda provido de um dos mais baixos IDHM do estado, e que até 0 estabelecimento da atividade em questão - no início da década de 90, sobrevivia basicamente do cultivo destinado à exportação da castanha do caju e da pesca de subsistência, em meio a um completo isolamento histórico.

Em sendo, sob uma percepção mais ampliada, pode-se, com bastante cientificidade (tendo se utilizado das metodologias quantitativa e qualitativa), realçar no destino - ele que é o Portão de Entrada para os Lençóis 
Maranhenses, os inúmeros ganhos e oportunidades geradas, visto o emprego tido como "ideal", dinamizando, portanto, as até então incipientes relações econômicas (e também sociais) do lugar.

\section{Referências}

ACERENZA, M.A. Administração do turismo: conceituação e organização. Bauru, SP: EDUSC, 2002.

AGUIAR, M R.; DIAS, R. Fundamentos do turismo. Campinas, SP: Alínea, 2002.

ARBACHE, J.S. O mercado de trabalho na atividade econômica do Turismo no Brasil. Brasília, DF: Editora da UNB, 2001.

ARENDIT, E.J. Introdução à economia do Turismo. Campinas, SP: Alínea, 2002.

BARRETTO, M. Manual de iniciação ao estudo do turismo. Campinas, SP: Papirus, 2003.

BENI, M.C. Análise estrutural do turismo. São Paulo: Senac, 2001.

BRASIL. Ministério do Turismo. Índice de competitividade do turismo nacional: 65 destinos indutores do desenvolvimento turístico regional. Barreirinhas, MA, 2014.

BURITI do Maranhão. Catálogo de Produtos. São Luís: Sebrae, 2010.

CARVALHO, L.C.P.; VASCONCELLOS, M.A.S. Introdução à economia do turismo. São Paulo: Saraiva, 2006.

CASASOLA, L. Turismo e ambiente. São Paulo: Roca, 2003.

DUPAS, G. Economia global e exclusão social: pobreza, emprego, estado e o futuro do capitalismo. São Paulo: Paz e Terra, 1999.

FERNANDES, I.P.; COELHO, M.F. Economia do turismo: teoria e prática. Rio de Janeiro: Elsevier, 2002.

FONTELES, J.O. Turismo e impactos socioambientais. São Paulo: Aleph, 2004.

FUNDAÇÃO INSTITUTO DE PESQUISAS ECONÔNOMICAS - FIPE. Multiplicadores de renda e emprego para o Brasil: Relatório final de pesquisa. São Paulo: FEA/USP, 1984.

GUIA BRASIL QUATRO RODAS. São Paulo: Abril, 2015.

INSTITUTO BRASILEIRO DE GEOGRAFIA E ESTATÍSTICA - IBGE. Censo demográfico 2007. Brasília, 2007. Disponível em: <www.cidades.ibge.gov.br>. Acesso em: 17 out. 2014.

INSTITUTO BRASILEIRO DE GEOGRAFIA E ESTATÍSTICA - IBGE. Brasília, 2015. Disponível em: <www.cidades.ibge.gov.br>. Acesso em: 02 out. 2016.

IGNARRA, L. R. Fundamentos do turismo. São Paulo: Pioneira, 2003. 
LAGE, B.H.G.; MILONE, P.C. Turismo na economia. São Paulo: Aleph, 2004.

LAGE, B.H.G.; MILONE, P.C. Turismo: teoria e prática. São Paulo: Atlas, 2000.

LEMOS, L. Turismo: que negócio é este? Uma análise da economia do turismo. Campinas, SP: Papirus, 1999.

LIMA, J.M.B. As belezas e os mistérios do rio Preguiças: Lençóis maranhenses, explosão de vida. Barreirinhas - MA, 2006.

MINARELLI, J.A. Empregabilidade: como ter trabalho e remuneração sempre. São Paulo: Gente, 1995.

MORANDI, S.; GIL, I.C. Espaço e Turismo. São Paulo: Copidart, 2002.

PIMENTA, M.A. Gestão de pessoas em turismo: sustentabilidade, qualidade e comunicação. Campinas, SP: Alínea, 2004.

RABAHY, W.A. Turismo e desenvolvimento: estudos econômicos e estatísticos no planejamento. Barueri, SP: Manole, 2003.

RAMOS, B. História de Barreirinhas: portal dos Lençóis Maranhenses. São Luís, 2008.

RODRIGUES, A.B. Turismo e desenvolvimento local. São Paulo: Hucitec, 2000.

RODRIGUES, A.B. Turismo e espaço: rumo a um conhecimento transdisciplinar. São Paulo: Hucitec, 2001.

RUSCHMANN, D. Turismo e planejamento sustentável: a proteção do meio ambiente. Campinas, SP: Papirus, 1997.

SERVIÇO NACIONAL DE APRENDIZAGEM COMERCIAL - SENAC. Século XXI: As novas ocupações: turismo e hotelaria. Relatório Final. Rio de Janeiro: Senac / DI / CAEP, 2000.

SILVA, D.L.B. Turismo em unidades de conservação: Contribuições para a prática de uma atividade turística sustentável no parque nacional dos lençóis maranhenses. Brasília: Universidade de Brasília, 2008.

WAHAB, S.E. Introdução à administração do turismo. São Paulo: Pioneira, 1977.

\section{Nota:}

Artigo derivado da Dissertação submetida ao Programa de Mestrado em Meio Ambiente e Desenvolvimento Urbano, da Universidade da Amazônia (UNAMA) em 15.01.2016. 
Marcelo Aragão Saldanha: Instituto Federal do Maranhão, Barreirinhas, MA, Brasil.

E-mail: marcelo.saldanha@ifma.edu.br

Link para o currículo Lattes: http://lattes.cnpq.br/7157840590052692

Leonardo Augusto Lobato Bello: Universidade da Amazônia, Belém, PA, Brasil.

E-mail: leonardo.bello@unama.br

Link para o currículo Lattes: http://lattes.cnpq.br/5449459117793556

Maria Lúcia Bahia Lopes: Universidade da Amazônia, Belém, PA, Brasil.

E-mail:marialucia.bahia@unama.br

Link para o currículo Lattes: http://lattes.cnpq.br/4629419656109116

Silvia Helena Ribeiro Cruz: Universidade Federal do Pará, Belém, PA, Brasil.

E-mail: silhcruz@gmail.com

Link para o currículo Lattes: http://lattes.cnpq.br/8432421463410679

Data de submissão: 17 de fevereiro de 2017

Data de recebimento de correções: 05 de maio de 2017

Data do aceite: 05 de maio de 2017

Avaliado anonimamente 